\title{
Effect of adhesive system and application strategy on reduction of dentin permeability
}

\section{Adriana Oliveira Carvalho(a) Marcelo Tavares de Oliveira ${ }^{(a)}$ Toru Nikaido(b) Junji Tagami(b) Marcelo Giannini(a)}

(a) Department of Restorative Dentistry, Piracicaba School of Dentistry, Campinas State University - Unicamp, Piracicaba, SP, Brazil.

(b) Department of Restorative Sciences, Graduate School, Tokyo Medical \& Dental University, Tokyo, Japan.

Declaration of Interests: The authors certify that they have no commercial or associative interest that represents a conflict of interest in connection with the manuscript.

Corresponding Author:

Marcelo Giannini

E-mail: giannini@fop.unicamp.br

Submitted: Dec 11, 2011

Accepted for publication: May 21, 2012

Last revision: Jun 06, 2012

\begin{abstract}
This study evaluated the effect of adhesive systems and application strategies on dentin hydraulic conductance (HC). The buccal enamel was removed from bovine incisors to simulate laminate cavity preparations. After removing the roots and the coronal pulp, the buccal dentin was treated with EDTA solution $(0.5 \mathrm{M})$ for 5 minutes, rinsed, ultrasonicated for 12 minutes and connected to a permeability device. HC of the specimens was measured at $10 \mathrm{psi}(\mathrm{n}=5)$. Permeability was measured before and after bonding procedures using G-Bond (GB), Clearfil Tri-S Bond (CTS), Hybrid Coat (HY), Bond Force (BF), Adper Easy Bond (AEB) Silorane (SI), Clearfil SE Bond (CSE) and Adper Scotchbond Multi-Purpose (SMP) adhesives systems, which were applied following three strategies: 1) according to the manufacturers' instructions; 2) two coats of all-in-one self-etching adhesives (GB, CTS, HY, BF, AEB) or priming step plus two coats of bonding resin for the other systems (SI, CSE and SMP); and 3) a thin layer of a flowable composite applied over one coat of all-in-one self-etching adhesives or primed surface for SI, CSE and SMP adhesives. No significant difference was observed among the application modes concerning their ability to reduce HC. None of the adhesives showed complete sealing (100\%) of the bovine tooth dentin. SI exhibited lower HC than SMP, however, they were not significantly different from the other systems. The results suggest that all systems tested result in an $\mathrm{HC}$ reduction of more than $90 \%$. The wet bonding technique seemed to be more sensitive for dentin sealing.
\end{abstract}

Descriptors: Dentin-Bonding Agents; Dental Bonding; Dentin Permeability.

\section{Introduction}

The hybridization of dental tissues promoted by adhesive systems was first described by Nakabayashi et al. in $1982 .{ }^{1}$ The authors etched the dentin with a $10-3$ solution $(10 \%$ citric acid $+3 \%$ ferric chloride) and used hydrophobic and hydrophilic groups (4-META/MMA-TBB) to infiltrate monomers into dentinal tubules and intertubular dentin. The resindentin interdiffusion zone or hybrid layer is the main bonding mechanism of contemporary bonding agents.

The development of dentin bonding agents has produced adhesives that are classified according to the etching type and number of steps required. $^{2-4}$ The hybridized layer produced by one-step self-etching or all- 
in-one adhesives has been considered a permeable membrane because they did not seal the bonded interface adequately. ${ }^{5-7}$ Previous one-step self-etching adhesives had low $\mathrm{pH}$ (less than 1) due to the composition which was based on acidic primers with a high concentration of hydrophilic monomers. This category of adhesives seems to produce a low degree of conversion, forming regions of incomplete polymerization, which are capable of attracting water and increasing permeability through the bonded interfaces. ${ }^{8-10}$

The one-step self-etching adhesive systems have since been modified; ${ }^{11-15}$ however, it is not known if these changes in composition improve the properties of the seal formed by this category of adhesives. The lack of proper marginal sealing leads to water/saliva infiltration, which can contaminate the mineralized dental tissues involved in the cavity preparation..$^{16,17}$ To improve the sealing ability of one-step self-etching adhesives, some authors have suggested the application of an additional layer of hydrophobic material in an attempt to reduce the concentration of hydrophilic monomers to be light cured., ${ }^{918-22}$

The importance of studying dentin permeability in relation to the sealing ability of adhesive systems is that, besides bonding the restorative material to the tooth, adhesive systems are responsible for sealing the resin-dentin interface against microleakage and avoiding restorative material debonding, which could compromise the restorations. ${ }^{2,16,17}$ The objective of this study was to measure fluid flow through the adhesive-dentin interfaces created by eight bonding agents using a permeability device. The null hypothesis was that the mode of application of the adhesives has no effect on dentin permeability.

\section{Methodology}

One hundred and twenty bovine incisors of similar size, stored in a saturated thymol (Labsynth, Diadema, Brazil) solution at $5^{\circ} \mathrm{C}$ for at least one month, were used in this study. Crown segments were obtained by removing the roots $1 \mathrm{~mm}$ below the cementum-enamel junction, using a watercooled diamond saw (Isomet, Buehler Ltd., Lake Bluff, USA). The pulp tissue was removed with \#80 Hedstroem files (Maillefer/Dentsply, Petrópolis,
Brazil). Teeth were divided into 24 groups $(\mathrm{n}=5)$.

The buccal enamel was removed during preparation of the laminate-like cavity, to expose the superficial dentin. A \#4138 diamond bur (KG Sorensen Ind. Com. Ltda., Barueri, Brazil) was used to prepare the teeth, and the bur was changed after every 5 teeth. The dentinal depth was controlled using a pincer-type caliper (Golgran, São Paulo, Brazil), which measured the remaining dentin thickness that was between 1.8 and $2.9 \mathrm{~mm}$. The incisor surfaces were reduced until the dentin tissue appeared and the cavity preparation was surrounded by at least $2 \mathrm{~mm}$ of enamel thickness, such as in the cervical area.

Each prepared tooth was attached to a polyester platform $(30 \times 30 \times 5 \mathrm{~mm})$, perforated in the center by an 18 gauge stainless steel tube fixed using cyanoacrylate glue (Super Bond, Loctite/Henkel, Diadema, Brazil). The tooth attached to the polyester platform was connected to a hydraulic pressure device (Figure 1) that delivered $10 \mathrm{psi}\left(703 \mathrm{~cm} \mathrm{H}_{2} \mathrm{O}\right.$ or $51.7 \mathrm{~cm} \mathrm{Hg}$ ) of water pressure during the measurement of dentin permeability. ${ }^{23}$ The hydraulic pressure device used in this study was similar to that designed by Sauro et al. ${ }^{6}$

Before applying the bonding agents, the teeth were treated with $0.5 \mathrm{M}$ EDTA $(\mathrm{pH} 7.4)$ for 5 minutes. Afterwards, they were rinsed with water for 1 minute, ultrasonicated (Maxi Clean 750, Unique, Indaiatuba, Brazil) in water for 12 minutes and each tooth was submitted to measurement of the maximum fluid filtration (MFF), which was assigned as $100 \%$ permeability. After measuring the MFF $(\mu \mathrm{L} /$ $\min$ ), a new smear layer was created on the dentin surface using a fine-grit-diamond bur (3139 finegrit, KG Sorensen Ind. Com. Ltda., Barueri, Brazil) for 30 seconds under water cooling. The adhesives were applied to the dentin while connected to the permeability device, but in the absence of pulpal pressure $^{6}$ in an attempt to simulate the clinical conditions in which anesthetic salts cause inhibition of pulp blood flow. ${ }^{24}$

Eight commercially available dentin adhesive systems were tested:

- Adper Scotchbond Multi-Purpose (3M ESPE, St. Paul, USA), 
- Clearfil SE Bond (Kuraray Medical Inc, Kurashiki, Japan),

- Silorane (3M ESPE AG, Seefeld, Germany),

- Adper Easy Bond (3M ESPE, St. Paul, USA),

- Bond Force (Tokuyama Dental Corp., Taitou-ku, Tokyo, Japan),
- Clearfil Tri-S Bond (Kuraray Medical Inc.),

- G-Bond (G-Cem, GC Corp., Tokyo, Japan) and

- Hybrid Coat (Sun Medical, Moriyama, Japan).

The adhesives were applied following three different application methods (Table 1):

Table 1 - Characteristics of adhesive systems and application modes.

\begin{tabular}{|c|c|c|c|c|}
\hline Adhesive system & Characteristics & Application mode 1 & Application mode 2 & Application mode 3 \\
\hline $\begin{array}{l}\text { Adper Scotchbond } \\
\text { Multi-Purpose }\end{array}$ & $\begin{array}{l}\text { 3-step } \\
\text { etch-and-rinse }\end{array}$ & $\begin{array}{c}\text { according to } \\
\text { manufacturer's instructions }\end{array}$ & $\begin{array}{l}\text { two coats of } \\
\text { adhesive resin }\end{array}$ & $\begin{array}{c}\text { flowable composite layer } \\
\text { over primed dentin }\end{array}$ \\
\hline Clearfil SE Bond & $\begin{array}{c}\text { 2-step } \\
\text { self-etching primer }\end{array}$ & $\begin{array}{c}\text { according to } \\
\text { manufacturer's instructions }\end{array}$ & $\begin{array}{l}\text { two coats of } \\
\text { adhesive resin }\end{array}$ & $\begin{array}{c}\text { flowable composite layer } \\
\text { over primed dentin }\end{array}$ \\
\hline Silorane & $\begin{array}{c}\text { 2-step } \\
\text { self-etching primer }\end{array}$ & $\begin{array}{c}\text { according to } \\
\text { manufacturer's instructions }\end{array}$ & $\begin{array}{l}\text { two coats of } \\
\text { adhesive resin }\end{array}$ & $\begin{array}{c}\text { flowable composite layer } \\
\text { over primed dentin }\end{array}$ \\
\hline Adper Easy Bond & $\begin{array}{c}\text { one-step } \\
\text { self-etching adhesive }\end{array}$ & $\begin{array}{c}\text { according to } \\
\text { manufacturer's instructions }\end{array}$ & $\begin{array}{l}\text { two coats of } \\
\text { adhesive }\end{array}$ & $\begin{array}{l}\text { one coat of adhesive }+ \\
\text { flowable composite layer }\end{array}$ \\
\hline Bond Force & $\begin{array}{c}\text { one-step } \\
\text { self-etching adhesive }\end{array}$ & $\begin{array}{c}\text { according to } \\
\text { manufacturer's instructions }\end{array}$ & $\begin{array}{l}\text { two coats of } \\
\text { adhesive }\end{array}$ & $\begin{array}{l}\text { one coat of adhesive }+ \\
\text { flowable composite layer }\end{array}$ \\
\hline Clearfil Tri-S Bond & $\begin{array}{c}\text { one-step } \\
\text { self-etching adhesive }\end{array}$ & $\begin{array}{c}\text { according to } \\
\text { manufacturer's instructions }\end{array}$ & $\begin{array}{l}\text { two coats of } \\
\text { adhesive }\end{array}$ & $\begin{array}{l}\text { one coat of adhesive }+ \\
\text { flowable composite layer }\end{array}$ \\
\hline G-Bond & $\begin{array}{c}\text { one-step } \\
\text { self-etching adhesive }\end{array}$ & $\begin{array}{c}\text { according to } \\
\text { manufacturer's instructions }\end{array}$ & $\begin{array}{l}\text { two coats of } \\
\text { adhesive }\end{array}$ & $\begin{array}{l}\text { one coat of adhesive }+ \\
\text { flowable composite layer }\end{array}$ \\
\hline Hybrid Coat & $\begin{array}{c}\text { one-step } \\
\text { self-etching adhesive }\end{array}$ & $\begin{array}{c}\text { according to } \\
\text { manufacturer's instructions }\end{array}$ & $\begin{array}{l}\text { two coats of } \\
\text { adhesive }\end{array}$ & $\begin{array}{l}\text { one coat of adhesive }+ \\
\text { flowable composite layer }\end{array}$ \\
\hline
\end{tabular}

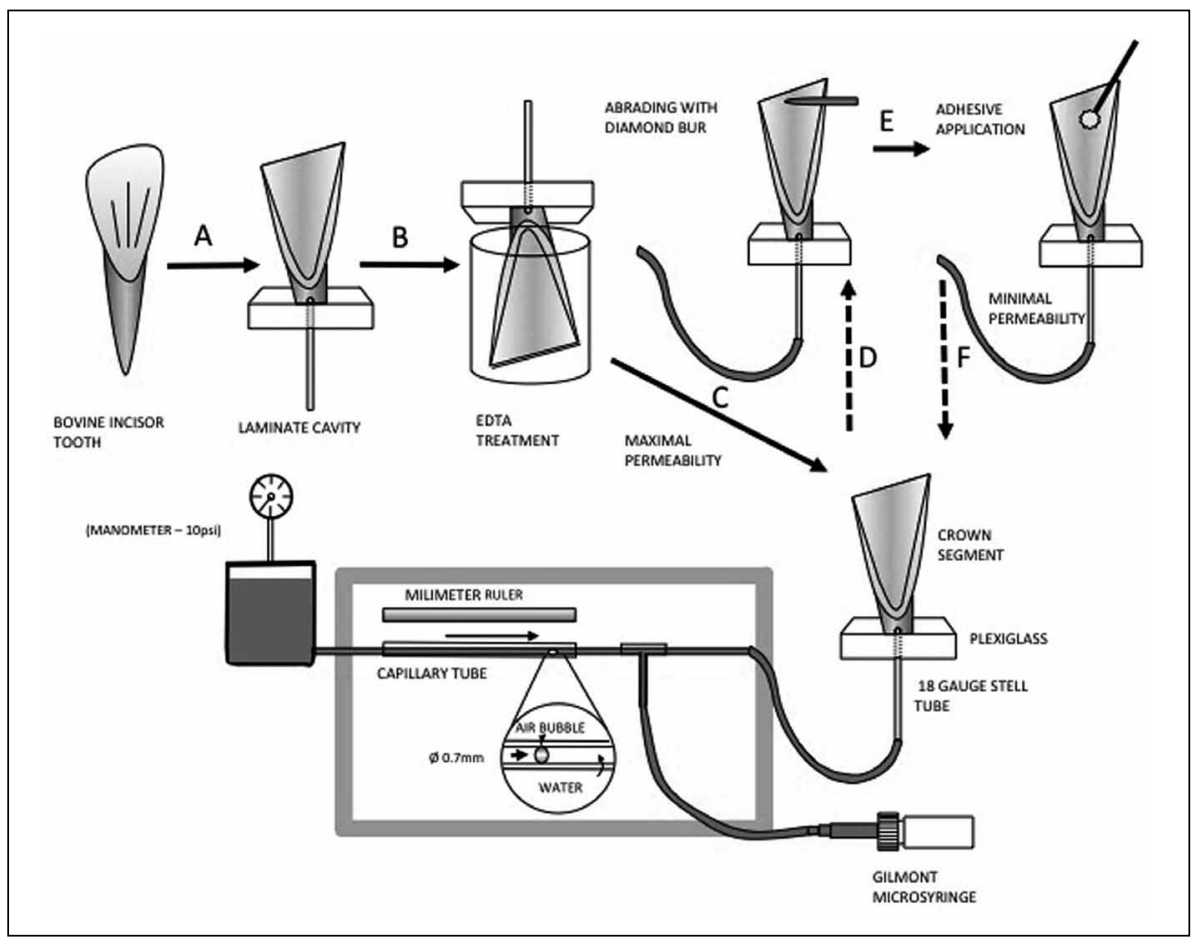

Figure 1 - Schematic representation of permeability measurement methodology. 
1. According to the manufacturers' instructions;

2. Two coats for the one-step self-etching adhesives. For the other adhesives the priming step (Primer, Clearfil Primer, or LS System Adhesive Primer, respectively) was followed by two coats of adhesive resin (Adhesive, Clearfil Bond, or LS System Adhesive Bond, respectively). Each coat was light-cured $\left(650 \mathrm{~mW} / \mathrm{cm}^{2}\right.$, Demetron LC, Kerr Corp., Orange, USA) separately for the time recommended by the manufacturer.

3. One coat for the one-step self-etching adhesives plus a thin layer of a flowable composite (FiltekFlow, 3M ESPE, St. Paul, USA). For the ScotchBond Multi-Purpose, Clearfil SE Bond and Silorane adhesives, the priming step was followed by the application of a thin layer of flowable composite (Filtek-Flow) instead of the adhesive resin. The adhesive coats and the low-viscosity resin were light-cured with the same curing unit.

After the bonding procedures, the fluid flow through the hybridized dentin (FFHD - final measurement) was remeasured to calculate the percentage reduction of fluid flow through the adhesivedentin interface or dentin seal provided by the adhesives. This represented the permeability after application of the adhesives relative to its maximum EDTA-treated pre-bonded value, or maximum fluid filtration (MFF - initial measurement), with each tooth serving as its own control. The equation below was used to calculate the percentage dentin sealing provided by the application of adhesive: ${ }^{25}$

$$
\text { Dentin sealing }(\%)=100 \times(\mathrm{MFF}-\mathrm{FFHD}) / \mathrm{MFF}
$$

The data were analyzed by two-way ANOVA (adhesive type and application mode were the factors under study) and Tukey test. Statistical significance was set at $\alpha=0.05$.

\section{Results}

Table 2 shows the mean percentage of dentin sealing provided by the different bonding procedures and the standard deviations of the experimental groups. Two-way ANOVA revealed a significant difference only for the factor "adhesive type" $(P=0.0495)$. Neither the "application mode" factor nor the interaction between the factors were significant $(P=0.1006$ and $P=0.6321$, respectively).

All three application modes resulted in a similar percentage of dentin sealing for the same adhesive used $(P>0.05)$. Only one significant difference was observed between the adhesives $(P<0.05)$ : the Silorane two-step self-etching adhesive $(96.6 \pm 2.6 \%)$ resulted in a higher percentage of dentin sealing than the Scotchbond Multi-Purpose three-step etchand-rinse adhesive $(92.4 \pm 4.4 \%)$. Both adhesives resulted in a similar percentage of dentin sealing to
Table 2 - Percentage of dentin sealing provided by bonding procedures (means \pm SD).

\begin{tabular}{c|c|c|c|c|c}
\hline $\begin{array}{c}\text { Adhesive } \\
\text { system }\end{array}$ & $\begin{array}{c}\text { Application } \\
\text { mode 1 }\end{array}$ & $\begin{array}{c}\text { Application } \\
\text { mode 2 }\end{array}$ & $\begin{array}{c}\text { Application } \\
\text { mode 3 }\end{array}$ & $\begin{array}{c}\text { Means of 3 } \\
\text { application modes }\end{array}$ & Tukey test \\
\hline $\begin{array}{c}\text { Adper Scotchbond } \\
\text { Multi-Purpose }\end{array}$ & $88.7 \pm 5.1$ & $93.9 \pm 5.5$ & $94.7 \pm 2.7$ & $92.4 \pm 4.4$ & $\mathrm{a}$ \\
\hline Clearfil SE Bond & $95.1 \pm 3.5$ & $96.6 \pm 2.2$ & $95.4 \pm 2.9$ & $95.7 \pm 2.9$ & $\mathrm{ab}$ \\
\hline Silorane & $96.4 \pm 2.4$ & $97.6 \pm 1.8$ & $95.8 \pm 3.6$ & $96.6 \pm 2.6$ & $\mathrm{~b}$ \\
\hline Adper Easy Bond & $94.6 \pm 3.1$ & $95.6 \pm 2.6$ & $96.9 \pm 1.2$ & $95.7 \pm 2.3$ & $\mathrm{ab}$ \\
\hline Bond Force & $94.9 \pm 3.1$ & $93.5 \pm 3.8$ & $94.7 \pm 4.7$ & $94.4 \pm 2.3$ & $\mathrm{ab}$ \\
\hline Clearfil Tri-S Bond & $94.5 \pm 3.8$ & $94.6 \pm 3.5$ & $96.3 \pm 2.6$ & $95.1 \pm 3.3$ & $\mathrm{ab}$ \\
\hline G-Bond & $94.9 \pm 1.9$ & $94.5 \pm 4.2$ & $96.4 \pm 2.4$ & $95.3 \pm 2.8$ & $\mathrm{ab}$ \\
\hline Hybrid Coat & $93.9 \pm 3.1$ & $95.9 \pm 2.5$ & $94.9 \pm 2.6$ & $94.9 \pm 2.7$ & $\mathrm{ab}$ \\
\hline ANOVA & $\mathrm{A}$ & $\mathrm{A}$ & $\mathrm{A}$ & & \\
\hline
\end{tabular}

Means of the 3 application modes followed by different lower case letters (column - comparison among adhesives) are statistically significant by Tukey test $(P<0.05)$. Groups having the same upper case letters (row - comparison among application modes) are not statistically significant by ANOVA ( $<0.05)$. 
other adhesives, and the difference between them was significant $(P<0.05)$.

\section{Discussion}

The dentin permeability measurements after EDTA-etching (MFF - maximum fluid filtration) and after bonding (FFHD - fluid flow through hybridized dentin) showed that no adhesive system completely sealed the dentin surface. However all adhesives sealed the dentin more than $90 \%$. The maximum mean value was $96.6 \pm 2.6 \%$ for the $\mathrm{Si}$ lorane two-step self-etching adhesive. This was significantly higher than that observed for the Scotchbond Multi-Purpose three-step etch-and-rinse adhesive $(92.4 \pm 4.4 \%)$. The application of flowable resin or an additional layer of adhesive resin neither improved nor impaired the dentin sealing. Thus, the null hypothesis was accepted since the application mode of the adhesives had no effect on percentage dentin sealing.

Because of the highly hydrophilic nature of some bonding agents, such as one-step self-etching systems, they can act as permeable membranes, attracting water and degrading faster than more hydrophobic adhesives. . $^{5,8,10,16}$ To overcome this early degradation, some investigations have revealed that the application of more hydrophobic resins over hybridized tissues provides better sealing of acid-etched dentin ${ }^{9,18-21}$ and higher bond strength of composite to dentin. ${ }^{19,20,22}$ In this study, the use of flowable resin or an additional layer of more hydrophobic adhesive did not improve the percentage dentin sealing of any type of adhesive.

As the results of this study indicated that the percentage dentin sealing was independent of the use of an additional layer of more hydrophobic resin, the correct application of adhesives was essential to reduce dentin permeability. This study also showed that only one adhesive layer of the one-step selfetching systems resulted in similar dentin hydraulic conductance when compared to use of an additional layer of the same adhesive or an additional layer of flowable or adhesive resin. Therefore, the quality of the adhesives is important since they are directly in contact with the dentin tissue and are responsible for sealing it against fluids that tend to pass through hybridized dentin and bond to the restorations. ${ }^{6,16}$ The seal provided by the bonding agents was measured only immediately after adhesive application. The durability of hybridization ensures that dentin sealing is maintained; however, the one-step selfetching adhesives may lose their effectiveness, increasing the hydraulic conductance faster than other types of adhesive systems. ${ }^{5-7}$ The bonding durability depends on the monomeric composition of each adhesive and the loss of marginal sealing can compromise a restoration. ${ }^{15,16}$ Further studies will investigate the durability of bonding and its relationship with the sealing of dentinal tubules.

Two two-step self-etching primers were evaluated: Clearfil SE Bond and Silorane. The acidic primers used hybridized smear plugs instead of removing them, sealing the dentinal tubules. ${ }^{3,26}$ The Clearfil SE Bond bonding resin is mixed with primer over the dentin surface and then both components are polymerized together in situ. For Silorane adhesive, primer and bond were light-cured separately; however, no difference was observed between these twostep self-etching primers. Changing the bonding resin to flowable resin or application of an additional layer of bonding resin did not alter the performance of either adhesive.

Two one-step self-etching adhesives are HEMA-free: G-Bond and Hybrid Coat. The HEMA monomer is commonly added to bonding agents and improves the stability of adhesive solutions that contain hydrophobic and hydrophilic components. However, HEMA has been considered vulnerable to hydrolysis because it is highly hydrophilic and absorbs water. ${ }^{27}$ While the Hybrid Coat adhesive contains 4-META, polyfunctional acrylate and monomethacrylates as functional monomers, G-Bond contains 4-MET and phosphoric ester-monomer as the acidic monomer. 4-META is a crystalline powder, which in contact with water can react and form 4-MET. Two carboxylic groups attached to the aromatic group of the 4-MET molecule provide the acidic characteristic that is important for the demineralization of the dentin and formation of the hybrid layer. $^{28}$

Adper Easy Bond, Bond Force and Clearfil Tri-S Bond one-step self-etching adhesives contain 
HEMA, Bis-GMA and a specific acidic monomer, methacrylated phosphoric ester, methacryloyloxyalkyl acid phosphate and 10-MDP, respectively. ${ }^{15}$ The presence of HEMA did not influence the results of this study; however, the monomeric composition of these adhesives could be a determinant that requires evaluating over time with the specimens stored in water.

The sensitivity of the bonding technique to acid-etched dentin has been considered more critical than self-etching adhesives. ${ }^{3,6,16}$ ScotchBond MultiPurpose uses the total-etch and moist bonding techniques and the water is provided from rinsing and dentin tubules. Adequate moisture control before bonding of etch and rinse adhesive is difficult, which can lead to compromising of the dentin hybridization. The lower numeric reduction on the hydraulic conductance or the percentage dentin sealing for this adhesive can be related to the moisture control

\section{References}

1. Nakabayashi N, Kojima K, Masuhara E. The promotion of adhesion by the infiltration of monomers into tooth substrates. J Biomed Mater Res. 1982 Mar;16(3):265-73.

2. Van Landuyt KL, Snauwaert J, De Munck J, Peumans M, Yoshida Y, Poitevin A, et al. Systematic review of the chemical composition of contemporary dental adhesives. Biomaterials. 2007 Sep;28(26):3757-85.

3. Sarr M, Kane AW, Vreven J, Mine A, Van Landuyt KL, Peumans $\mathrm{M}$, et al. Microtensile bond strength and interfacial characterization of 11 contemporary adhesives bonded to bur-cut dentin. Oper Dent. 2010 Jan-Feb;35(1):94-104.

4. Inoue G, Nikaido T, M Foxton R, Tagami J. The acid-base resistant zone in three dentin bonding systems. Dent Mater J. 2009 Nov;28(6):717-21.

5. Reis AF, Bedran-Russo AK, Giannini M, Pereira PN. Interfacial ultramorphology of single-step adhesives: nanoleakage as a function of time. J Oral Rehabil. 2007 Mar;34(3):213-21.

6. Sauro S, Pashley DH, Montanari M, Chersoni S, Carvalho RM, Toledano M, et al. Effect of simulated pulpal pressure on dentin permeability and adhesion of self-etch adhesives. Dent Mater. 2007 Jun;23(6):705-13.

7. Kim J, Mai S, Carrilho MR, Yiu CK, Pashley DH, Tay FR. An all-in-one adhesive does not etch beyond hybrid layers. J Dent Res. 2010 May;89(5):482-7.

8. Tay FR, Pashley DH. Have dentin adhesives become too hydrophilic? J Can Dent Assoc. 2003 Dec;69(11):726-31. technique, which can produce more permeable hybrid and adhesive layers due to the presence of water during polymerization. Even the application of two layers of bonding resin did not improve the acidetched dentin sealing.

\section{Conclusions}

No significant difference was observed among the application modes concerning their ability to reduce hydraulic conductance. None of the adhesives showed complete sealing $(100 \%)$ of the bovine tooth dentin. The Silorane adhesive showed lower hydraulic conductance than SMP; however, they were not different from the other systems.

\section{Acknowledgments}

This study was supported by grants from CAPES and CNPq (303587/2007-5), Brazil.
9. Reis AF, Giannini M, Pereira PN. Long-term TEM analysis of the nanoleakage patterns in resin-dentin interfaces produced by different bonding strategies. Dent Mater. 2007 Sep;23(9):1164-72.

10. Takahashi M, Nakajima M, Hosaka K, Ikeda M, Foxton RM, Tagami J. Long-term evaluation of water sorption and ultimate tensile strength of HEMA-containing/-free one-step self-etch adhesives. J Dent. 2011 Jul;39(7):506-12.

11. Perdigão J. New developments in dental adhesion. Dent Clin North Am. 2007 Apr;51(2):333-57.

12. Brackett WW, Tay FR, Looney SW, Ito S, Haisch LD, Pashley $\mathrm{DH}$. Microtensile dentin and enamel bond strengths of recent self-etching resins. Oper Dent. 2008 Jan-Feb;33(1):89-95.

13. Soderholm KJ, Soares F, Argumosa M, Loveland C, Bimstein E, Guelmann M. Shear bond strength of one etch-and-rinse and five self-etching dental adhesives when used by six operators. Acta Odontol Scand. 2008 Aug;66(4):243-9.

14. Tajima K, Nikaido T, Inoue G, Ikeda M, Tagami J. Effects of coating root dentin surfaces with adhesive materials. Dent Mater J. 2009 Sep;28(5):578-86.

15. Van Landuyt KL, Mine A, De Munck J, Jaecques S, Peumans M, Lambrechts $P$, et al. Are one-step adhesives easier to use and better performing? Multifactorial assessment of contemporary one-step self-etching adhesives. J Adhes Dent. 2009 Jun;11(3):175-90.

16. De Munck J, Van Landuyt K, Peumans M, Poitevin A, Lambrechts $\mathrm{P}, \mathrm{Braem} \mathrm{M}$, et al. A critical review of the durability 
of adhesion to tooth tissue: methods and results. J Dent Res. 2005 Feb;84(2):118-32.

17. Klautau EB, Carneiro KK, Lobato MF, Machado SMM, Souza Jr MHS. Low shrinkage composite resins: influence on sealing ability in unfavorable C-factor cavities. Braz Oral Res. 2011 Jan-Feb;25(1):5-12.

18. Carrilho MR, Tay FR, Sword J, Donnelly AM, Agee KA, Nishitani Y, et al. Dentine sealing provided by smear layer/ smear plugs vs. adhesive resins/resin tags. Eur J Oral Sci. 2007 Aug;115(4):321-9.

19. Albuquerque M, Pegoraro M, Mattei G, Reis A, Loguercio AD. Effect of double-application or the application of a hydrophobic layer for improved efficacy of one-step self-etch systems in enamel and dentin. Oper Dent. 2008 Sep-Oct;33(5):564-70.

20. Reis A, Albuquerque M, Pegoraro M, Mattei G, Bauer JR, Grande RH, et al. Can the durability of one-step self-etch adhesives be improved by double application or by an extra layer of hydrophobic resin? J Dent. 2008 May;36(5):309-15.

21. Arisu HD, Eliguzeloglu E, Uctasli MB, Omurlu H, Turkoz E. Effect of multiple consecutive adhesive coatings on microleakage of class v cavities. Eur J Dent. 2009 Jul;3(3):178-84.

22. De Goes MF, Giannini M, Di Hipólito V, Carrilho MRO, Daronch M, Rueggeberg FA. Microtensile bond strength of adhesive systems to dentin with or without application of an intermediate flowable resin layer. Braz Dent J. 2008 JanMar;19(1):51-6.

23. Pashley DH, Depew DD. Effects of the smear layer, Copalite, and oxalate on microleakage. Oper Dent. 1986 Summer;11(3):95-102.

24. Yoon MJ, Kim E, Lee SJ, Bae YM, Kim S, Park SH. Pulpal blood flow measurement with ultrasound Doppler imaging. J Endod. 2010 Mar;36(3):419-22.

25. Bacelar-Sá R, Carvalho AO, Puppin-Rontani RM, Ambrosano GMB, Nikaido T, Tagami J, Giannini M. Effects of water storage on bond strength and dentin sealing ability promoted by adhesive systems. J Adhes Dent. Forthcoming 2012.

26. Van Meerbeek B, Yoshihara K, Yoshida Y, Mine A, De Munck J, Van Landuyt KL. State of the art of self-etch adhesives. Dent Mater. 2011 Jan;27(1):17-28.

27. Reis AF, Carrilho MR, Ghaname E, Pereira PN, Giannini M, Nikaido T, et al. Effects of water-storage on the physical and ultramorphological features of adhesives and primer/adhesive mixtures. Dent Mater J. 2010 Nov;29(6):697-705.

28. Unemori M, Matsuya Y, Matsuya S, Akashi A, Akamine A. Water absorption of poly(methyl methacrylate) containing 4-methacryloxyethyl trimellitic anhydride. Biomaterials. 2003 Apr;24(8):1381-7. 